\title{
GENERAL DISCUSSION OF THE PAPERS
}

\author{
By Kiwerski, Jenik et al., Gasper, Sutton et al., Rosman et al., Key, Hurford, \\ RichaRd, WeBb et al. and ChaHAL.
}

\section{Subject. Social Situation of Paraplegics and Tetraplegics.}

Chairman. Dr G. G. Reynolds.

Dr Key (South Africa). Dr Sutton, I note that only 12 per cent of the 75 patients had upper limb involvement. Forty per cent of paraplegics had wheelchairs; yet, 77 per cent of your patients were given wheelchairs. Could you please explain this?

DR SUTTON (U.K.). The wheelchairs were supplied to people who were unable to walk. The figures relate not only to powered but also to ordinary manually propelled wheelchairs.

Dr Pinkerton (Canada). We are in the midst of doing a similar study to that of Dr Sutton, but looking at his numbers and the fact that 18 per cent had no disability in that they walked normally, this alters the figures considerably, especially when you are dealing in percentages. In our study we eliminated those who walked without any aids, and those who had normal or near normal bowel and bladder control and the figures which we will eventually produce may be more valid. I should like Dr Sutton to comment on his 18 per cent who had no disability regarding walking.

Dr SutTon. We reviewed the 75 patients in toto and 16 per cent were placed in 'Group I' with no, or only mild disability. The figures have to be accepted in our paper on this basis.

SiR George Bedbrook (Australia). I wish to ask Dr Jenik and Dr Sutton what financial support they get from local bodies or from governments in relation to the social resettlement of paraplegic and quadriplegic persons in their communities? This seems to me to be a very important point in economics, permitting people to leave hospital earlier and return to their home, as mentioned in Dr Jenik's paper, but I would also like to have some idea of the extent of the assistance given.

DR JENIK (Switzerland). The support from the government is regulated by invalidity insurance for all inhabitants of Switzerland, and this is in the roo per cent theoretical invalidity of I IOO Swiss francs per month, and of course there are people who receive pensions and insurance monies, and there are people who get 4000 francs per month, and can pay for the reconstruction of their house. There is no other support from the government for such rebuilding.

DR SutTon. We looked at the gross income of each of these 75 handicapped people and looking at the range of their income, 3 per cent earned $£ 500$ or less; 10.4 per cent had between $£ 500$ and $£$ I000 a year, from all available grants, but excluding compensation awards. Twenty four per cent had between $£_{1000}$ and $£ 2000$ a year; I 5 per cent between $£ 2000$ and $£, 3000$ a year; 2 I per cent between $£ 3000$ and $£ 4000$ a year; then only 7.5 per cent had between $£ 4000$ and $£ .5000$ a year; but i9 per cent had between $£ 5000$ and $£ 6000$. As I mentioned, about 20 per cent of these 75 patients had a reasonable expectation of a large compensation award by virtue of the accident.

Sir GEORGE BEDBRook. I wish to find out if there was any direct granting to patients for greater modifications, and there obviously is not, and yet I think that this has been one of the very big advances we could expect in the area of paraplegia. We have had this direct granting now for some years in Western Australia and it has paid dividends in that patients are able to go home without too much concern about access problems and I think it has increased our numbers attending hospital on a day basis so 
that we have cut down the number of in-patients, and when you estimate the cost of beds, a few thousand dollars spent propitiously (not from their incomes at all) before the patient goes home, makes a big difference to the social establishment.

DR HAMzA $(E g y p t)$. I would like to ask a question regarding the paper by Dr Jenik and Dr Zach. I found that the incidence of divorce and of separation was very low. Divorce was only $4 \cdot 4$ per cent and separation just $\mathrm{I} \cdot 2$ per cent and I wondered if it would be possible to give me some information about the 'normal' incidence of divorce and separation.

DR JENIK. 5.4 per cent is the pre-injury status and it remains unchanged as yet, and in the normal population in the first year of marriage in Switzerland, there is a 40 per cent divorce rate.

Dr Dollfus (France). First of all, I must congratulate our Swiss friends. I think that they have earned the world championship for return to work, because 70 per cent is very high indeed. I wish to ask Dr Sutton the reasons for discrimination concerning car insurance. I understand from what you say, that comprehensive insurance for cars has been refused to certain patients.

DR SUTTON. I have no information on this point. There is a tendency for administrators to feel that handicapped people should not be driving cars, and certainly they are very worried about attacks of spasm and other symptoms that may suggest that a person may lose control of a car.

DR Dollfus. I think that this should be made public. This is the Year of the Disabled Person, and I think that it is a very important point indeed. The French figures show that disabled people have fewer accidents than so-called able-bodied people, and I feel that this is discrimination, and is a matter that should be published in the Press. I am also very interested in your figures on public inaccessability. As Chairman of ECTA, I would like more detailed information, and when I receive the figures, I would like to publish them.

DR NAKAMURA (fapan). I should like to say something about the situation in Japan, where much electrical and computer work is done. I employ 400 very severely disabled people, including 70 paraplegics and ten tetraplegics in my factory, and the value of annual output is about Io million U.S. dollars. We also have supermarkets and our own bank in the factory.

ChaIRMAN. Dr Key made an interesting point in her presentation about the progressive involvement of the patients themselves in attempting to solve their own social situations, and I think that we as health professionals must begin to encourage these people to solve their own problems. In other words, we must work with the disabled and not for the disabled.

Sir GEORGE BEDBROoK. I wish to ask Barbara Richards how much activity she thinks the investigation is engendering in the paraplegic personnel in Queensland? Are these problems being taken up with politicians regularly? Does their point of view agree with the professional point of view?

BARBARA RichaRDS (Australia). Certainly, all the views that are expressed in my paper are those of the paraplegics and tetraplegics themselves, none of them are mine. During this International Year of the Disabled Person (and I am Chairman of the State Accommodation Committee), I have found that we are working very closely with disabled people right across the board; and not just the spinal cord injured. They are very active and approach politicians. We hold seminars, lectures and public meetings several times a week, and I think that we are beginning to make ourselves heard. We also hope that it is an on-going process, and that these various committees that have been set up will not be disbanded on 3I December.

Dr Agerholm (U.K.). We now know enough about paraplegics and tetraplegics to be able to produce some relatively easy assessment for government planning. We have heard Sir George Bedbrook say that in one part of Australia a great deal of cash is given direct to the person, whereas in another part of Australia there is obviously a tremendous problem over this. Most require a proper income by virtue of their handicap and their disability; but there are two main items that cause particular concern: housing 
and a car. We require statistics, and a proper presentation of actual residual handicaps, so that accurate comparisons can be made between different countries.

Sir GEORGE BEDBROOK. There is a publication from the World Health Organisation which I am sure Paul Dollfus knows about, on these points, that is the classification of a disability, handicap and impairment, and this is now being tried out in three or four areas of the world.

Dr Agerholm. Classification is a major problem. There is the Agerholm classification which is a rival to Philip Woods' W.H.O. classification, which has never been used. We have even surveyed the whole of Northern Ireland with ours, and I am going out to Australia to use it there.

Dr Hamza. In Egypt we are confronted with these problems when a patient is discharged: poor income of the patient, unsuitable housing for the disabled, difficulty in using public transport and difficulty in obtaining specialised medical advice when discharged to their village. To overcome this we have built a project of faith and hope which is headed by our First Lady. Money has come from taxes to provide facilities with a capacity of more than Iooo beds and a large sports stadium for paraplegics and tetraplegics. Suitable housing and medical care, and suitable work are priorities. Secondly, there is now a law which allows a severely disabled person to be able to get IoO per cent to I 50 per cent of his salary prior to the accident for the rest of his life, and there is also a law which allows him to use public transport freely. However, our goal is to send every patient back to live with his family as an active member in the society, when the conditions are suitable and safe and not a risk to his life.

Dr Donovan (U.S.A.). I would like to compliment Dr Chahal not only on his paper but on the work that he is doing. Would he firstly enlarge on what it took him to get the funding and the building that we saw actually materialise; and secondly, there is a criticism that one hears from time to time in having a special Home in that it becomes too easy to discharge patients to the Home rather than finding a way to mainstream the patient back into the community. From your figures I gathered that you did not have this problem because the ones that went to the Home was small, but how would you reply to my criticism?

DR ChaHAl (India). The cost of our first 25 beds was four lakhs in Indian rupees, eight of these is equal to a dollar. The administrative facilities, the dining-hall, and the other halls, cost another five lakhs. We insisted that accommodation for the staff must be provided on the campus, because in a town like Puna, it is difficult to get a house. We employ retired soldiers so that they get their pension and they work with us for three-quarters of the average salary. If the price for a medical attendant is 500 rupees, he is grateful for a house for 350 to 400 rupees. Some of the funds come from the people, and during the I97I war people were emotionally worked up, and offered me crutches, calipers and wheelchairs. However, I said no. I had a very good sensible lady from Bombay. She said, 'I'll raise the money', and she raised I6 lakhs. Mrs Ghandi gave eleven lakhs to help us, and we have put this in a fixed deposit and the interest is available each year. I also get a grant every year from the Government. Half the ideas are not mine, they are Sir George Bedbrook's, I learnt from him. Discipline of patients is very important, and at times I require to be strict, and after three warnings the person is discharged from the Home.

DR SILVER (U.K.). I would like to congratulate Colonel Chahal on his superb paper. There is a rather depressing picture in this country in that although the Duchess of Gloucester (D.O.G.) House, and Lyme Green were very successful when they were set up, patients are now very resistant to going to hostels; they are demanding to return to their own environment, for various reasons industrial and otherwise; these hostels are no longer functioning and are due to be phased out. I think it does arise from this morning's papers that patients are demanding to be returned to their own homes and are not willing to accept hostel accommodation, and I am sure that as patients become more sophisticated and demanding, Colonel Chahal will find that they are going to ask to go home and demand facilities.

Mr RavichandRan (U.K.). A lakh is 100000 units. Colonel Chahal, in you 
experience during the War, how many paraplegics were there in the Army, and how many come to you, what proportion? My second question is, are there any other similar centres in India?

Colonel ChaHAL. Eighty per cent of our patients say they want to go to their homes. In the Armed Forces, the Regimental Centre contributes the amount required for alteration to the patient's room and bathrocm. We give him the equipment, the wheelchair, tricycle and so on. The expense involved for altering his house to make a pavement or ramp or provide a bathroom, is provided by the Regimental Centres. Some of my colleagues comment that our Hcme is a four-star hotel and I am aiming at including a swimming pool, so it will become a five-star hotel. The concept I have learned is that you either look after the spinal injured very well or you don't look after them properly. If they still feel homesick they are welcome to go home for a holiday and then return. Regarding Ravichandran's questions, we have found that every day of war gave us one paraplegic depending upon the day; the Israeli friends have probably had a similar experience; but if we have war on two fronts, which we had in I97I, then we get two patients a day; so in 25 days I admitted 52 patients. Our annual average admission is 55 , out of which 47 are due to trauma and seven to eight are from disease. Regarding other Centres in India, we now have about eight spinal centres. Our problem is one of numbers. A spinal injuries centre has $20-30$ beds but in that province there may be as many as $200-250$ patients a year. So they cannot admit and treat all patients, and more centres will be developed in the next 5 years.

The Chairman then closed the Session, saying that he was delighted to be a part of it and he said that $\mathrm{emphasis}$ must be placed on the resocialisation and resettlement of spinal injured patients. In a country like the United States the cost of medical care was such that it served little purpose to spend Io 000 to 50 cco dollars treating a person in hospital and then sending him home to an environment in which he fell between the cracks with a high degree of morbidity and mortality. 